\title{
Stimulation of spore germination of wood-decomposing Hymenomycetes by carbon dioxide
}

\author{
Veikko Hintikka \\ The National Research Council for Agriculture and Forestry \\ and Finnish Forest Research Institute, Unioninkatu $40 \mathrm{~A}$, \\ Helsinki 17, Finland
}

\begin{abstract}
The effect of carbon dioxide on the spore germination of 23 wooddecomposing Hymenomycetes was investigated by introducing $1 \%, 5 \%$, and $20 \%$ carbon dioxide - air mixtures into desiccators, in which spores were germinated on Hagem agar. Compared to ordinary air, low concentrations $(1 \%$ and $5 \%$ ) markedly stimulated the germination rate of several species. Species growing in living tree stems were stimulated most effectively (Spongipellis borealis, Polyporus squamosus, Pholiota aurivella and Fomitopsis annosa). Stimulation took place at different $\mathrm{pH}$ values and seems to be independent of the acidifying action of carbon dioxide. Ecological aspects of the stimulation are discussed.
\end{abstract}

\section{Introduction}

Spores of wood-decomposing Hymenomycetes are often produced in great quantities, and a freshly cut exposed wood surface may receive spores within minutes, as experiments with Fomitopsis annosa have indicated (Rishbeth 1959). As the wood surface receives also spores of many other fungi as well as bacteria, the conditions at the wood surface evidently have a selective effect on the invading fungal population. In addition, tree wounds may remain susceptible to infection for only a relatively short time due to the formation of resin, tyloses, and the effects of other micro-organisms. For instance, spores of Fomes igniarius have been found to germinate on wounds of Populus only during the first 4 days (MANION \&
FRENGH 1968).

One of the many factors active at the wood surface is carbon dioxide. Living and decomposing wood contains considerable amounts of carbon dioxide which often exceed the concentration in the air by 100 500 times, (Thacker \& Good 1952, JENSEN 1969), and decomposing wood continuously produces $\mathrm{CO}_{2}$ (KLINGSTRÖM 1965, Good, Basham \& Kadzielawa 1968). Evidently carbon dioxide diffuses from the wood and affects the fungal spores at the surface. The present experiments were devised to investigate the effects of carbon dioxide on the germination of some wood-decomposing Hymenomycetes.

\section{Methods}

Spore deposits of wood-decomposing fungi were obtained by keeping a freshly collected basidiocarp above a sterile $9 \mathrm{~cm}$ petri dish for 4-12 hours. Dishes with spore deposits 
were kept at $+5^{\circ} \mathrm{C}$, and used for experiments within 6 months of storage. As many wooddecomposing fungi require external carbon supply for germination (WALKINSHAW \& Scheld 1965, Fries 1966, Manion \& French 1969), Hagem agar was used as a standard medium (composition: glucose $5 \mathrm{~g}$, malt extract $5 \mathrm{~g}, \mathrm{KH}_{2} \mathrm{PO}_{4} 0.5 \mathrm{~g}, \mathrm{MgSO}_{4} 7 \mathrm{H}_{2} \mathrm{O}$ $0.5 \mathrm{~g}, \mathrm{NH}_{4} \mathrm{Cl} 0.5 \mathrm{~g}, \mathrm{FeCl}_{3} 1 \%$ solution $0.5 \mathrm{ml}$, agar $15 \mathrm{~g}$, dist. $\mathrm{H}_{2} \mathrm{O} 1000 \mathrm{ml}$ ). This medium, on which the mycelia of the species investigated grew well, proved to be superior to plain water agar. A spore suspension in sterile water was spread over the surface of the agar in a $5 \mathrm{~cm}$ petri dish which was placed, upside down in $10 \mathrm{l}$ desiccator. The desiccators were flushed with 1001 carbon dioxide-air mixtures prepared by Aga Oy, Kilo, from 150 atm. pressure containers, and immediately closed. $1 \%$, $5 \%$, and $20 \%$ carbon dioxide-air mixtures were used. The amount of gas was checked by an air-flow meter made by VEB Prüfgerätewerk, Medingen. At suitable intervals a dish was taken out of the desiccator in order to follow the germination process, and the desiccator containing the remaining dishes was flushed with $100 \mathrm{l}$ of the same gas mixture and immediately closed. The germination was terminated by placing a few drops of formaldehyde on the opposite lid of the dish. In each dish 1000 spores were counted. A spore was regarded as having germinated when the germination tube was more than half the length of the spore. In the case of rapidly growing species, the mycelia from the spores which germinated first made the counting inaccurate within a short time, and the main emphasis was laid upon the initiation of the germination, and Fuller's method (1967) for cumulative germination percentage proved to be too laborious. Control dishes in ordinary air were kept under similar conditions in closed desiccators, but no flushing was done. The experiments were carried out at room temperature $\left(20-24^{\circ} \mathrm{C}\right)$. The results are presented in Table 1. The significance test is based on the fact that

$$
\mu=\frac{\mathrm{p}_{1}-\mathrm{p}_{2}}{\sqrt{\frac{2 \mathrm{p} 100-\mathrm{p})}{\mathrm{n}}}}
$$

where $p_{1}$ and $p_{2}$ are percentages of germination, $\mathrm{p}=1 / 2\left(\mathrm{p}_{1}+\mathrm{p}_{2}\right)$ and $\mathrm{n}=100$, is approximately normally distributed.

\section{Interaction of $\mathrm{pH}$ and carbon dioxide}

As carbon dioxide in higher concentrations tends to acidify the cultural medium, the effect of $\mathrm{pH}$ on the action of carbon dioxide on spore germination was investigated by germinating spores on agar of different $\mathrm{pH}$ values and in different concentrations of carbon dioxide. A buffer, prepared from 0.1 $\mathrm{M} \mathrm{Na} \mathrm{NPO}_{4}, 0.1 \mathrm{~N} \mathrm{HCl}$, and $0.1 \mathrm{M}$ $\mathrm{KH}_{2} \mathrm{PO}_{4}$ was added to Hagem agar of double concentration in the ratio of $1: 1$. The results are given in Fig. 1.

It is evident that some interaction between
$\mathrm{pH}$ and carbon dioxide stimulation occurs, especially in Coprinus micaceus and in Spongipellis borealis. On the other hand, the marked stimulation of carbon dioxide cannot, as a whole, be attributed to the action of $\mathrm{pH}$, since spores of Pholiota aurivella had, in 41 hours, scarcely germinated in ordinary air at any of the $\mathrm{pH}$ values. Conversely, in carbon dioxide abundant germination had set in. In all the other experiments, Hagem agar of $\mathrm{pH} 5.5$ was used as a standard medium.

\section{Results}

Table 1 shows the results of the present experiments. The most rapid germination was obtained in many cases in $1 \%$ or $5 \%$ carbon dioxide, and the difference between ordinary air and carbon dioxide is often statistically significant. Broadly speaking there seems to exist a certain correlation between the amount of stimulation and the habitat. Especially promoted are species which grow in nature within living trunks of 

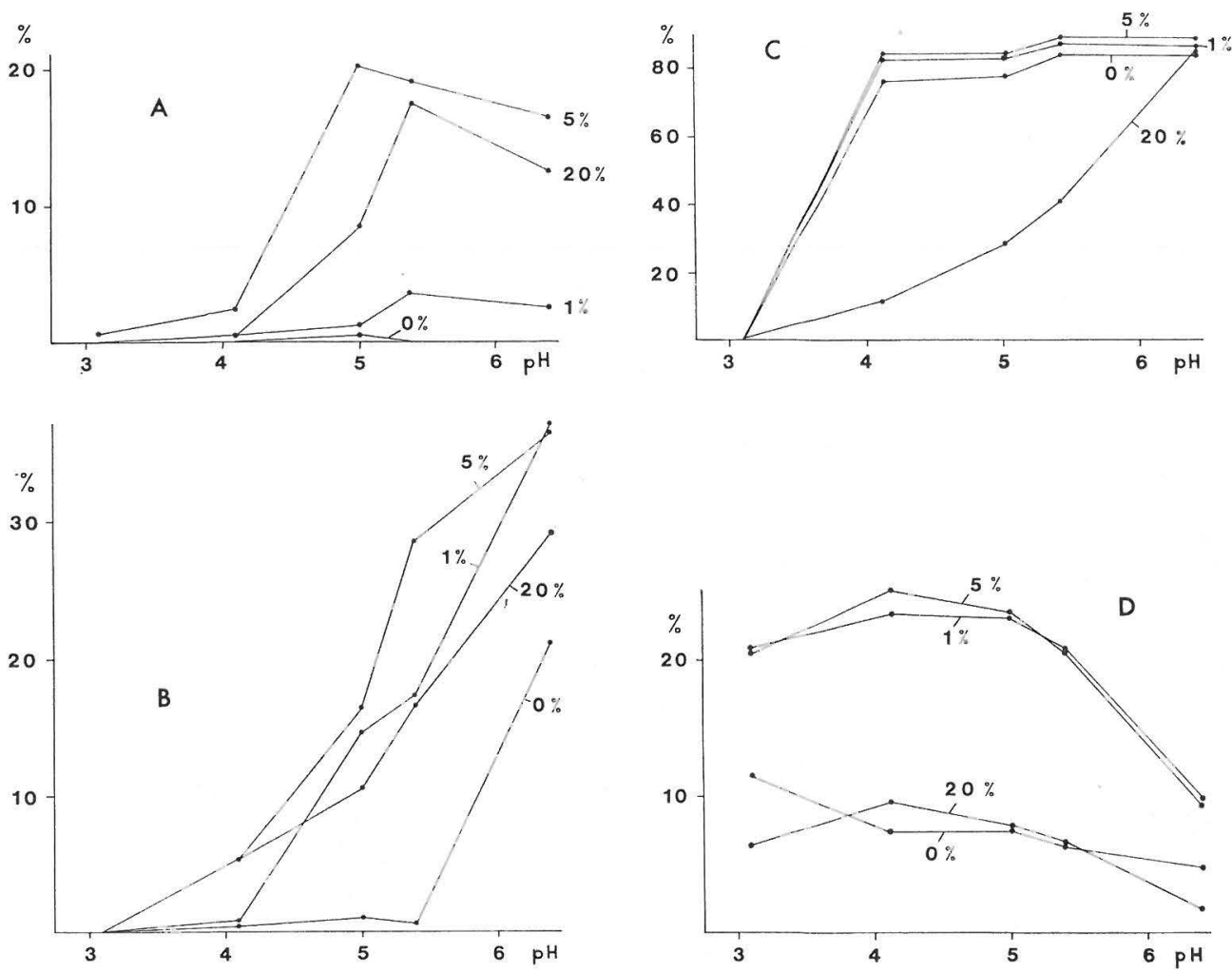

Fig. 1. The effect of carbon dioxide and $\mathrm{pH}$ on the germination of a: Pholiota aurivella, b: Coprinus micaceus, c: Fomes fomentarius, and d: Spongipellis borealis. Horizontal axis: $\mathrm{pH}$, vertical axis: percentage of germination.

trees (Polyporus squamosus, Fomitopsis pinicola, Pholiota aurivella and Spongipellis borealis). $20 \%$ carbon dioxide in the air was in most cases inhibitive, a remarkable exception being Pholiota aurivella. Weaker decomposers, like the Mycena species were already inhibited in $5 \%$ carbon dioxide. As a comparison three soil fungi, Lepista nuda, Collybia dryophila, and Trichoderma viride were taken, of which the first-named was slightly stimulated by $\mathrm{CO}_{2}$, and the lastnamed clearly inhibited.

\section{Discussion}

A stimulation of spore germination of fungi by carbon dioxide is found in several species (Cochrane 1958, Tabak \& Cooke 1968). A few species require this gas for the intiation of germination, e.g. Aspergillus niger (Yanagita 1957), Chaetomium globosum (Buston et al. 1966) and Penicillium griseofulvum (Fletcher \& Morton 1970). Among wood-decomposing species, the spores of Schizophyllum commune do not grow in atmospheres totally devoid of $\mathrm{CO}_{2}$, although in ordinary air they germinate readily $\left(\mathrm{HA}_{\mathrm{A}}\right.$ FIZ \& NiederRruem 1963).
Based on the experiments presented above, the stimulatory effect of carbon dioxide concentrations higher than in ordinary air on the spore germination of certain wood-decomposing Hymenomycetes seems to be so pronounced that in certain cases it may have ecological significance in the infection process and could be regarded as a developmental adaptation to the compact structure of wood, which prevents ventilation. Similarly the mycelial growth is often stimulated in this ecological group of fungi (THACKER \& Good 1952, Hintikka \& Korhonen 1970, 
Table 1. The effect of carbon dioxide on the germination of wood-decomposing fungi. Asterisks indicate statistically significant stimulation compared with ordinary air $(0.03 \%)$.

\begin{tabular}{|c|c|c|c|c|c|}
\hline Species & $\begin{array}{l}\text { Time } \\
\text { hours }\end{array}$ & \multicolumn{4}{|c|}{$\begin{array}{l}\text { Percentage of germination in air and in different } \\
\mathrm{CO}_{2} \text {-air mixtures }\end{array}$} \\
\hline Armillariella mellea & $\begin{array}{l}16 \mathrm{~h} \\
22 \mathrm{~h} \\
40 \mathrm{~h}\end{array}$ & $\begin{array}{r}6.3 \\
14.2 \\
26.5\end{array}$ & $\begin{array}{r}5.5 \\
13.7 \\
20.6\end{array}$ & $\begin{array}{r}4.8 \\
13.9 \\
20.9\end{array}$ & $\begin{array}{r}4.8 \\
7.8 \\
17.2\end{array}$ \\
\hline Collybia dryophila & $66 \mathrm{~h}$ & 6.9 & 4.9 & 3.0 & 0.0 \\
\hline Coprinus micaccus & $\begin{array}{l}17 \mathrm{~h} \\
24 \mathrm{~h} \\
41 \mathrm{~h}\end{array}$ & $\begin{array}{l}63.2 \\
64.3 \\
84.2\end{array}$ & $\begin{array}{l}70.6 * * \\
79.7 * * * \\
85.7\end{array}$ & $\begin{array}{l}69.5 * * \\
81.6 * * * \\
81.2\end{array}$ & $\begin{array}{l}63.0 \\
69.3^{*} \\
75.8\end{array}$ \\
\hline Fomes fomentarius & $\begin{array}{ll}21 \mathrm{~h} \\
48 \mathrm{~h}\end{array}$ & $\begin{array}{l}84.8 \\
93.4\end{array}$ & $\begin{array}{l}87.4 \\
95.2\end{array}$ & $\begin{array}{l}88.6^{*} \\
95.4\end{array}$ & $\begin{array}{l}58.7 \\
84.1\end{array}$ \\
\hline $\begin{array}{l}\text { Fomitopsis annosa, } \\
\text { conidia from an aseptic culture }\end{array}$ & $22 \mathrm{~h}$ & 25.6 & $30.2^{*}$ & 27.7 & 10.1 \\
\hline F. pinicola & $16 \mathrm{~h}$ & 60.4 & $92.7 * * *$ & $95.8 * * *$ & $91.8 * * *$ \\
\hline Gymnopilus penetrans & $\begin{array}{l}24 \mathrm{~h} \\
41 \mathrm{~h}\end{array}$ & $\begin{array}{l}0.3 \\
0.3\end{array}$ & $\begin{array}{l}1.2^{*} \\
0.9\end{array}$ & $\begin{array}{l}1.7 * * \\
2.6 * * *\end{array}$ & $\begin{array}{l}1.6^{* *} \\
2.4^{* * *}\end{array}$ \\
\hline Hirschioporus abietinus & $\begin{array}{l}19 \mathrm{~h} \\
42 \mathrm{~h}\end{array}$ & $\begin{array}{l}10.2 \\
10.9\end{array}$ & $\begin{array}{l}11.3 \\
18.6^{* * *}\end{array}$ & $\begin{array}{l}8.2 \\
16.1 * * *\end{array}$ & $\begin{array}{r}6.4 \\
12.1\end{array}$ \\
\hline Hypholoma capnoides & $\begin{array}{r}6 \mathrm{~h} \\
12 \mathrm{~h} \\
18 \mathrm{~h} \\
24 \mathrm{~h}\end{array}$ & $\begin{array}{l}20.6 \\
70.5 \\
70.8 \\
80.7\end{array}$ & $\begin{array}{l}25.8 * * \\
75.8 * * \\
76.0 * * \\
80.0\end{array}$ & $\begin{array}{l}39.2 * * * \\
74.9 * \\
74.6 \\
78.6\end{array}$ & $\begin{array}{r}9.8 \\
64.5 \\
72.8 \\
78.6\end{array}$ \\
\hline H. fasciculare & $\begin{array}{l}12 \mathrm{~h} \\
18 \mathrm{~h} \\
24 \mathrm{~h}\end{array}$ & $\begin{array}{l}11.6 \\
16.7 \\
31.3\end{array}$ & $\begin{array}{l}16.3^{* *} \\
23.8^{* * * *} \\
32.7\end{array}$ & $\begin{array}{l}10.9 \\
16.2 \\
24.5\end{array}$ & $\begin{array}{r}0.7 \\
7.7 \\
15.7\end{array}$ \\
\hline H. sublateritium & $\begin{array}{l}12 \mathrm{~h} \\
18 \mathrm{~h} \\
24 \mathrm{~h}\end{array}$ & $\begin{array}{l}64.4 \\
67.3 \\
78.6\end{array}$ & $\begin{array}{l}72.5^{* * * *} \\
67.2 \\
82.3^{*}\end{array}$ & $\begin{array}{l}65.3 \\
65.9 \\
66.9\end{array}$ & $\begin{array}{l}10.6 \\
58.8 \\
62.1\end{array}$ \\
\hline Kuehneromyces mutabilis & $\begin{array}{l}12 \mathrm{~h} \\
18 \mathrm{~h} \\
24 \mathrm{~h}\end{array}$ & $\begin{array}{l}30.0 \\
64.8 \\
79.2\end{array}$ & $\begin{array}{l}61.0 * * * \\
75.1 * * * \\
72.5\end{array}$ & $\begin{array}{l}49.7 * * * \\
77.9 * * * \\
77.8\end{array}$ & $\begin{array}{l}13.4 \\
39.9 \\
41.0\end{array}$ \\
\hline Lepista nuda & $\begin{array}{l}66 \mathrm{~h} \\
90 \mathrm{~h}\end{array}$ & $\begin{array}{l}0.6 \\
1.0\end{array}$ & $\begin{array}{l}0.7 \\
1.4\end{array}$ & $\begin{array}{l}1.9^{*} \\
2.4^{*}\end{array}$ & $\begin{array}{l}0.6 \\
2.1 *\end{array}$ \\
\hline Mycena galericulata & $47 \mathrm{~h}$ & 17.6 & 11.2 & 13.5 & 14.2 \\
\hline M. inclinata & $\begin{array}{l}65 \mathrm{~h} \\
90 \mathrm{~h}\end{array}$ & $\begin{array}{l}25.0 \\
23.5\end{array}$ & $\begin{array}{l}11.6 \\
16.2\end{array}$ & $\begin{array}{l}14.1 \\
19.1\end{array}$ & $\begin{array}{l}0.3 \\
2.0\end{array}$ \\
\hline M. maculata & $\begin{array}{l}47 \mathrm{~h} \\
65 \mathrm{~h}\end{array}$ & $\begin{array}{l}1.5 \\
3.5\end{array}$ & $\begin{array}{l}2.2 \\
3.1\end{array}$ & $\begin{array}{l}2.7 \\
4.4\end{array}$ & $\begin{array}{l}1.6 \\
4.7\end{array}$ \\
\hline Pholiota aurivella & $\begin{array}{l}41 \mathrm{~h} \\
47 \mathrm{~h}\end{array}$ & $\begin{array}{l}0.0 \\
0.3\end{array}$ & $\begin{array}{l}1.4 * * * \\
3.7 * * *\end{array}$ & $\begin{array}{l}13.3^{* * *} \\
29.0^{* * *}\end{array}$ & $\begin{array}{l}11.6^{* * *} \\
29.6^{* * *}\end{array}$ \\
\hline P. lenta & $41 \mathrm{~h}$ & 3.2 & 3.0 & 4.9 & 0.2 \\
\hline P. squarrosa & $\begin{array}{r}90 \mathrm{~h} \\
122 \mathrm{~h}\end{array}$ & $\begin{array}{l}0.8 \\
0.8\end{array}$ & $\begin{array}{l}1.0 \\
1.0\end{array}$ & $\begin{array}{l}1.7 \\
3.0 * * *\end{array}$ & $\begin{array}{l}1.4 \\
5.4 * * *\end{array}$ \\
\hline Polyporus squmosus & $\begin{array}{r}66 \mathrm{~h} \\
90 \mathrm{~h} \\
122 \mathrm{~h}\end{array}$ & $\begin{array}{l}11.4 \\
19.1 \\
23.7\end{array}$ & ${ }^{62.9^{* * *}}-$ & $\begin{array}{l}21.7 * * * \\
27.4^{* * * *} \\
33.5^{* * *}\end{array}$ & $\begin{array}{l}2.6 \\
18.6 \\
38.0 * * *\end{array}$ \\
\hline Piptoporus betulinus & $\begin{array}{ll}21 \mathrm{~h} \\
48 \mathrm{~h}\end{array}$ & $\begin{array}{l}31.2 \\
43.8\end{array}$ & $\begin{array}{l}39.3^{* * *} \\
47.0\end{array}$ & $\begin{array}{l}36.4^{*} \\
48.7^{*}\end{array}$ & $\begin{array}{l}18.5 \\
46.9\end{array}$ \\
\hline Psathyrella spadicea & $\begin{array}{ll}18 \mathrm{~h} \\
24 \mathrm{~h} \\
28 \mathrm{~h}\end{array}$ & $\frac{1.9}{15.6}$ & $\begin{array}{r}1.0 \\
8.3 \\
14.9\end{array}$ & $\begin{array}{r}0.7 \\
6.0 \\
10.5\end{array}$ & $\begin{array}{l}0.0 \\
0.3 \\
1.5\end{array}$ \\
\hline Pycnoporus cinnabarinus & $72 \mathrm{~h}$ & 3.5 & 3.8 & 2.8 & 0.6 \\
\hline Spongipellis borealis & $\begin{array}{ll}24 & h \\
33 & h \\
44 & h\end{array}$ & $\begin{array}{l}0.6 \\
2.6 \\
7.2\end{array}$ & $\begin{array}{c}1.5^{*} \\
12.3^{* * *} \\
36.9 * * *\end{array}$ & $\begin{array}{l}0.9 \\
19.6^{* * *} \\
42.3^{* * *}\end{array}$ & $\begin{array}{l}0.1 \\
7.8 * * * \\
29.0 * * *\end{array}$ \\
\hline Trichoderma viride & $\begin{array}{l}18 \mathrm{~h} \\
42 \mathrm{~h}\end{array}$ & 14.5 & 3.7 & $\begin{array}{r}0.0 \\
99.8\end{array}$ & $\begin{array}{r}0.0 \\
99.9\end{array}$ \\
\hline
\end{tabular}


see also Jensen 1967). The actual concentration of carbon dioxide as well as that of oxygen on the surface of wood is not readily determinable because changes in the tempera- ture and air pressure may cause spores to be sucked into tracheas and tracheids, where higher concentrations of $\mathrm{CO}_{2}$ may prevail.

\section{Acknowledgements}

This study was carried out at the Finnish Forest Research Institute under a grant from the National Research Council for Agriculture and Forestry.

\section{REFERENCES}

Buston, H. W., M. O. Moss \& D. Tyrrell, 1966: The influence of carbon dioxide on growth and sporulation of Chaetomium globosum. - Trans. Brit. Mycol. Soc. 49, 387-396.

Cochrane, V. W., 1958: Physiology of fungi. 524 pp. New York.

Fletcher, J. \& A. G. Morton, 1970: Physiology of the germination of Penicillium griseofulvum conidia. - Trans. Brit. Mycol. Soc. 54, $65-81$.

Fries, N., 1966: Chemical factors in the germination of spores Basidiomycetes. - The fungus spore, ed. by M. F. Madelin, 189199. London.

Fuller, W. H., 1967: A method for determining the cumulative germination of spores over a period of time. - Can. J. Bot. 45, 17751776.

Good, H. M., J. T. Basham \& S. D. Kadzielava, 1968: Respiratory activity of fungal associations in zones of heart rot and stain in sugar maple. - Can. J. Bot. 46, 27-36.

Hafiz, A. \& D. J. Niederpruem, 1963: Studies on basidiospore germination in Schizophyllum commune. - Am. J. Bot. 50, 614-615.

Hintikka, V. \& K. Korhonen, 1970: Effects of carbon dioxide on the growth of lignicolous and soil-inhabiting Hymenomycetes. Comm. Inst. Forest. Fenn. 69: 5, 1-29.

Jensen, K. F., 19:67: Oxygen and carbon dioxide affect the growth of wood-decaying fungi. - Forest Science 13, 384-389.
- 1969: Oxygen and carbon dioxide concentrations in sound and decaying red oak trees. - Ibid. 15, 246-251.

Klingström, A., 1965: CO2 production as a measure of decay activity in wood blocks. Studia Forestalia Suec, 26, 1-20.

Manion, P. O. \& D. W. French, 1968: Inoculation of living aspen with basidiospores of Fomes igniarius var. populinus. - Phytopathology $58,1302-1304$.

- 1969: The role of glucose in stimulating germination of Fomes igniarius v. populinum basidiospore. - Phytopathology 59, $293-29.6$.

Rishbeth, J., 1959: Dispersal of Fomes annosus Fr. and Peniophora gigantea (Fr.) Massee. Trans. Brit. Myc. Soc. 42, 243-260.

TABAK, H. H. \& W. B. Cooke, 1968: The effects of gaseous environments on the growth and metabolism of fungi. - The Botanical Rewiew 34, 126-252.

Thacker, D. G. \& M. Good, 1952: The composition of air in trunks of sugar maple in relation to decay. - Can. J. Bot. 30, 475485.

Walkinshaw, C. H. \& H. W. Scheld, 1965: Response of spores of Cronartium fusiforme and Lenzites saepiaria to metabolites. Phytopathology 55, 475-476.

Yanagita, T., 1957: Biochemical aspects on the germination of conidiospores of Aspergillus niger. - Arch. f. Mikrobiol. 26, 329-344. 